\title{
French museum in decay' fights for its life
}

[PARIS] Decades of neglect by successive governments have allowed France's National Museum of Natural History in Paris to fall into a dangerous state of decay, according to a report by a government advisory panel.

A serious fire last August at the museum, for example, came within metres of the world's largest herbarium, a tinderbox of 8 million specimens. Had the herbarium been destroyed it would have been an "international catastrophe", says Philippe Taquet, head of the palaeontology department and a former director of the museum.

A crisis has been reached, warns the 270 page report by the $\mathrm{CNE}$, an independent advisory committee set up in 1984 to evaluate public scientific and cultural agencies. The government has now agreed to carry out a detailed audit of the museum's needs before the summer, in what it describes as a first step towards a comprehensive renovation programme.

The report points out that much of the museum, which houses one of the world's leading natural history collections, fails to meet minimum safety requirements. Apart from fire, staff are at risk from such hazards as electrocution, dangerous roofs and poorly stored chemicals.

The herbarium's operating budget is "zero francs, zero centimes", points out one researcher, while its electrical system, like that of much of the museum, is antiquated and still operates at 110 volts.

Similarly, a notice pinned to the wall of the palaeontology department casually informs researchers that no outgoing mail will be sent until the money needed to buy stamps arrives from the 1997 budget, which officially amounts to around FF250 million (US $\$ 45$ million).

The origin of the problem, according to the review panel, is that the museum has been one of the lowest spending priorities of its parent body, the education ministry.
Rectifying matters "is a question of political will", says Henri De Lumley, the museum's director. He adds that "the state needs to design a rolling plan of renovation over 15 to 20 years". But he is under no illusion that the education ministry alone will be able to come up with the funds needed, and says that an emergency injection of funds will be needed from the state.

This hint seems aimed at President Jacques Chirac. The recent FF500-million renovation of the museum's Great Hall of Evolution was not funded by the education ministry, but on the personal initiative of Chirac's predecessor, François Mitterrand (see Nature 362, 280; 1993).

The report also criticizes the museum itself for paying insufficient attention to the upkeep of its collections. These include 7 kilometres of 'carrots' from deep ocean drilling, 2 million fossils, 150 million insects, and 1.5 million vertebrates, including 1 million fish, 200,000 amphibians and reptiles, and 272,000 birds and mammals.

Part of the problem is that the upkeep of the collections is left to researchers. They are under such pressure to publish papers that they have little time to devote to the collections on which they rely, says De Lumley.

He points out that many of the museum's researchers are employees of the Centre National de la Recherche Scientifique (CNRS) or other research organizations, and that such agencies evaluate performance in terms of research and not on the basis of contributions made to maintaining collections or creating exhibitions.

Resolving the problems requires the renovation of storage facilities for the collections, and the creation of a corps of dedicated curators, according to the report. De Lumley supports both proposals, but argues that they can be accomplished only if the museum's budgets for collections are increased to a "realistic"level.

\section{Pig heart transplant surgeon held in jail}

[NEW DELHI] An Indian heart surgeon who last month carried out an unsuccessful attempt to transplant a pig's heart into a 32-year-old man is being held in custody in Guwahati, the capital of Assam state.

Bail has been denied to the surgeon, Dhaniram Baruah, and two colleagues - C. J. James and Jonathan Ho of the Prince of Wales Medical Institute in Hong Kong who assisted in the operation. The patient died soon afterwards.

The three have been held in jail in Guwahati since 10 January after being charged with violating the Organ Transplant Act of 1994. Their arrests followed complaints to the police from relatives of the patient that the death took place "under mysterious circumstances".

Baruah, who runs a heart institute in Guwahati, is believed to have carried out the transplant to generate publicity. His arguments that the law did not apply to Assam state, and that he had the patient's consent for the surgery, were both rejected by the Indian court. The court also rejected a separate bail application for Ho filed by his wife. The case will be heard next month. If convicted, the doctors could receive a fine of up to Rs 10,000 (US\$300) and a jail term of five years.
K.S.Jayaraman

\section{IMAGE UNAVAILABLE FOR COPYRIGHT REASONS}

Skeleton staff? Extra funding, as the Great Hall of Evolution received, would help the museum.

The broad thrust of the report is that the museum needs to refocus its activities on its three specific missions - conservation of collections, research, and informing the public - and in a way that promotes understanding of biodiversity, evolution and the environment.

It also criticizes the complexity of the accounting systems used by the museum, claiming that this makes it difficult to work out what share of the budget is devoted to each of the museum's missions. The Cours des Comptes is completing an audit of the museum, which is expected to be released next month.

The report argues that although many of the museum's fundamental research laboratories are internationally renowned, much of the work is essentially medical, or duplicates that done elsewhere. This represents a drain on the museum's scant resources that it cannot afford, says the report, arguing that money would be better spent by focusing on research that only the museum can do.

Some of the criticism can be traced to resentment by traditional systematicists at the high costs of such facilities as DNA sequencing laboratories, when they have no funds to maintain their collections.

But Taquet admits that the museum has suffered from an overemphasis on molecular biology over the past two decades, and that systematics is enjoying a comeback. "I agree that the museum cannot be in all areas of research and that we need to focus on those areas that are central to our mission."

De Lumley has begun streamlining the museum's research activities by regrouping its laboratories within interdisciplinary "institutes", such as "ecology and management of biodiversity".
DeclanButler 